T. O. Davis

P. B. Raven*

C. L. Shafer, M.D.

A. C. Linnebur, M.D.**

J. M. Bustos

L. D. Wheat

D. D. Douglas, Section Leader

"Consultant, Professor, Institute for Aerobics Research, 11811 Preston Rd., Dallas, TX 75320.

* "Consultant, Los Alamos Medical Center, Los Alamos, NM 87544.

An Alfirmative Action / Equal Opportunity Employer 
Previous reports in this series, unclassified, are LA-5470-PR, LA-5574-PR, LA-5758-PR, and LA-6426-PR.

This work was supported by the US Energy Research and Development Administration, Division of Safety, Standards, and Compliance.

Printed in the United States of America. Available from National Technical information Service

U.S. Department of Comrnerce

5285 Port Royal Road

Springfield, VA 22161

Price: Printed Copy $\$ 4.00$ Microfiche $\$ 3.00$

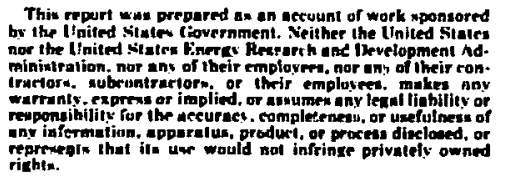


TES"IRATOR STUDIES FOR THE

ERDA DIVISION OI SAFETY, STANDARDS, ANL COMPLIANCE

$$
\text { JULY } 1,1975 \text { THROUGH JUNE } 30,1976
$$

Fesnilator studies for the

ERDA Division of Saftey, Standaris, and Cumplianot

Jusv 1,1975 through Junt 70,1976

by

This report was prepanes as an accerunt of work

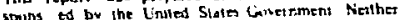
the Unied Stater new the Linuled Siate Kartag

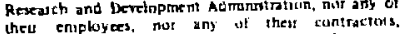
sutciontracturs, or they employess. makes any, wartanty. express os implest, ot atsuntes any legal

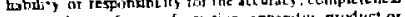

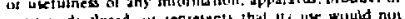

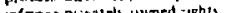

T. O. Davis,

P. B. Raven,

C. L. Shafer,

J. M. Bustos,

L. D. Wheat,

A. C. Linnebur,

Darrel D. Douglas, Section Leader

I. PHYSIOLOGIC STUTiY - T. O. Davis, P. B. Raven,

C. L. Shafer, 4. C. Linntbur, d. M. Bustos,

L. D. Whe $a t$

\section{A. Introuduction}

In 1974 tine Eneriv Pesearch and Development

Adninistration (ERDA) Division of Safety, standards, and

Comoliance (DSSC) saw the need to obtain data un the

onvsiolurical effect on the wearer of a respirator, fur

criteria for future standards. Discussions betwetn ERDA DSSC

and The Lus Alanos Scientific Laburatury (LASL) Resoirator

Research and Develodnent Section (RRDS) defined the orimary

goals as determining what $\in f f e c t$ wearing a respirator had on

worker performance, and which ohysiological paranters an

industrial ohysician should cunsider when examining an

employet who will be wearing a resnirator whije working.

As a result of these discussions, E?DA DSSC funjed LASL

RRDS during FY 1976, for a physiological study of the effect

of wearing a respirator.

B. ReView of Literature

A literature review showed that while ouite a bit of work had been done in this area, the majority was in two categuries; generai and uverly soecific. The peneral articles dealt with the effect of gentral phvsiojogical parameters, for exanple, insoiratury and exoiratory resistances. 1, ? The specific articles dealt with a sincle parameter for a single device, fur examole, inspired air. temperature for closed-circuit seff-contained breathing 
apparatus (SCRA), ?" or with a singit device fur a sateific industry. 5 suth types of articjes helsed us in odanning for testing, however they did not suoply what was nestef for ERDA DSSS work.

The literature review also showed that ire rionters were recognized as havins a hisher-than-nolmal inoidenat of cardiovascular and pulmongrv diseases, believed to stem from their occupation. $6-10$

\section{FY 1975 study ioals}

Discussions between FRDA DSSC and LASI, qRDS had defined overall nete and quals, as describet in sectiun I. 1 . Scra's are widejv lased by EPDA contracturs and centrad industry.

Fire fighters in generai, and FRDA firt firiters in particular, use heavy SCBA resniraturs in the audrse uf dut . The literature review had shoin that fire fi-hters have a higher than normal incidence of cardiovaseular and nuimonary diseases. Therefort, the filst stufy wouli look at this trot of $r \in s p i r a t o r$.

The type of resoirator most widely used by fire fichters is an oDen-circuit SCBA. The most common roded is a scott anmin unit, with a requator wilich aar be unerated in either. demand or pressure-demand mode, and with a facepiect with a pressure-loaded exhalation valve. This was the device ustd during testing ( $s \in=a$ iso Section I. D. 4 ).

During FY 1976, LASL comoleted a pilot study on the effect of wearing an ooen-aircuit SCEA. The pilot study cuvered varying workluads, effect of the weight of the unit alune, tfects of demand and pressure-demand operation, heat build-uo inside the facediece, and differentiated the subjects into smokers and non-smokers.

\section{Research Methods}

1. Subjects. Fifietr subjects were chusen frum ?? voiunteers. The subjects were FFnA fire fiohters, and tests were cunducted during duty hours. Of the 15 subjects, 8 were non-smukers and 7 were smoker.s. Fach subject was given a complete physical examination inciuding blout and urint analysis, chest $X$ ray, and resting ECF. After Dassing the physical, each subject was given a pruce naximai stress $t \leq s t 11$ to determine his fitness for the experimental testina. Onlv healthy individuals were chosen as subjects. Fach subject:

a. read and sirned informed consent furm, ADpenjix $A$.

b. had a $0.5-h$ instruction and oractice session, learning to walk and rua on a treadmill, beforte

the maximai test.

c. had two $0.5-h$ oractice sessiuns, learning to waik

and run on a treadmill while weaidis an SCBA befure startin? the experimental testing.

Fur ad tests the subject reported dressed in shorts tennis shoes, having fasted from food and drink for $5 \mathrm{~h}$, and fulduiling 3 he of $s i \in t$. 
Seven of the 2 o vojurtets welt nut usut as test suniects ful the rujiunino reasuns:

Two diuoned uut of the study ful dersunal reasuns,

Two could not thifre maxinas otifurmance on the treaswj.l due to minor orthobedic nroblens,

Thlet had abnolnaj lesults furing the Rruce screbning tesi and welte referled to their nlivate ohysicians.

2. Experimentai Hezhud. Fach subject was testel loul tines; without resoiratur weirht or factnitec as a co!ll:0! situation (condition 1); with resnilatur weight but no lacepieat (conditiun ?); with itiont and factpitct, derand mode (contition 3); and with weirht and factpiect. Diessure-demand mode (condition 4). Aij tests were likfurled at tl.t sane lucatiun, uniel simisl envilunnenta: coriations, and at anjruxingtely the sane time of day. Redeated ribasures ant landum-crder npesentation of conditions Nere usted during the test.

The subjects wert tested on a treadnili, using the siandard Pruoe Protocut. A ohvsician nonitored the ECG sianals during testin and recovely. A five-chest-jead EC nonituling svstem was used to nonizor pusitions I, II, AVF, AVL, $V_{5}$, tht backoack harness straos tisjudged the V5 teletrode. su a $y_{4}$ position was used. Blood oressure (left arm) was nonitored using a standard niessure cuff and stethoscose. Furehtad tenptrature (TFore) was monitured with a thernistor thermometer. (YeIjois-Sorings), set Fir. 1 .

Innediatedy afier the tleatrill stress test each subject was evaiuated Jurins, a 5-nin, seated, recovery period. Respiratur apoaratus worn during tssting was also worn throurh the recovely oeriod. A blood sannle was drawn at 4 min into the recoverv period to determine the bioud lactate $1 \in V \in \perp$.

3. Techniouts of iteasurtnenz. i. nuinton treadmill capabit uf soetd fiom zelo to $400 \mathrm{~m} / \mathrm{min}$ at qrades of zero to $25 \%$ was used for the test. Priol to the test the subject was seated in a char for a 5-min rest neriod. Resting blood pressure, heart rate, and multilead electrocardiograms were obtained foldowing the jest period. The subject then stoud and started walkinr on the treajmill. The titevation and speed changes, called stapes, used during the test are shown in Fig. 2 .

Each test was terminated when the subject could no longtr be motivated to auntinue, or if any significant abnormalities occurred in ECG, or blood pressure, or on the decision of the attending nhysician. A 5 min seated recovery period followed the test during which heart rate, forthead temperature, and blood pressure were monitoied. Differences ir heart rate, bioud pressure, TFore, and test duration time were used as a prediction of atrobic capacity, i.t., VO2 max. 13 Andropriate corrections were made for 


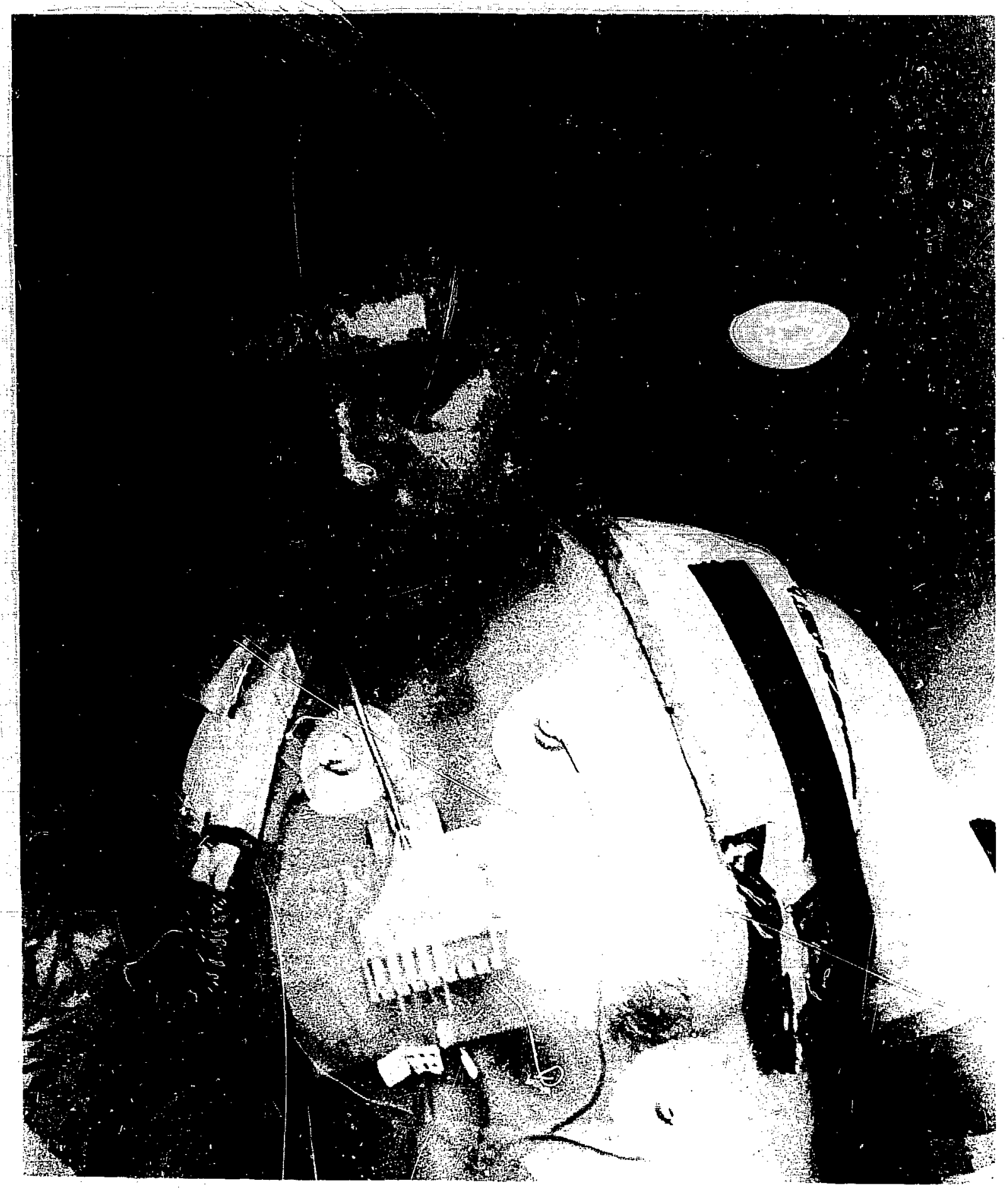

Fig. 1 .

Test leads attached to test subject. 


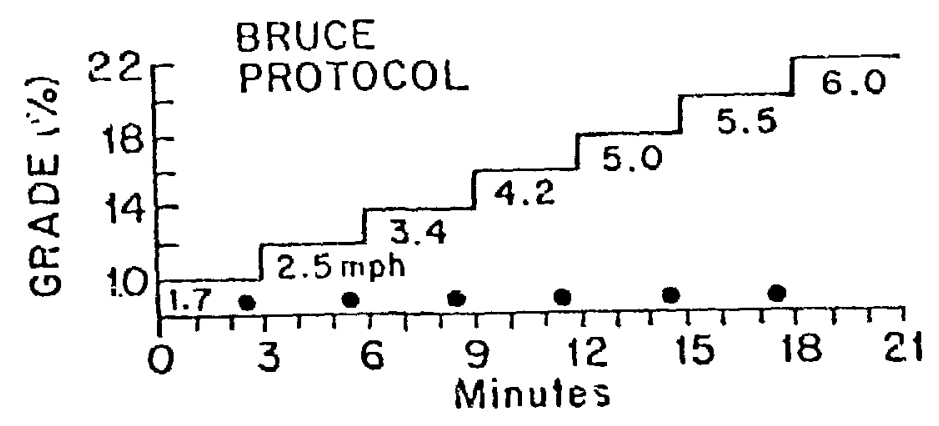

- Represents the time of blood pressure, heart rate, multilead ECG and forehead temperature determinations.

Fig. 2 .

Schematic of Bruce Treadmill Test Frotorol.

the decreased barometric pressure at Los Alamos (Elevation-2200 m; barometric nitessurt $=535 \mathrm{~mm}$ Hs). 14

Electrucardiugram nuniturint and nuttijeat recurding were ubtained using an viunics caldio-scanner ant cardiu-chalter. The heart rate and ECr waveferm vere constantiy nunitoret ant intermittentiv recurded. Sienificant wavefurm changes were analyzed at the time by the attending nhysician and "nost hoc" by the LASL consulting cardiolorist. giour pressure teterminations were ubtained by indirect brachial auscultatior using the Riva-Rocci method and the fourth sound k'as used to define diastolic pressure since during moderately heavy exercise the fourth and fifth sounds are distinctiy separate. Systolic index (heart rate and systojic oressure) was also calculated as an indtx of mvocardial oxymen cust. The 4-min ousi-txelcise bloud samoje was anajyzed for lactate level by enzymatic analysis 15 and used for determining the overall degree of physical stress.

4. Test Resoiratul. The respirator used was a scott Air-Pak, an open-circuit self-cuntained breathing apparatus (SCBAi), with a full race mask, set Fiz. 3. The units used were Bureau-of-Mines adouved. The stantard facediece, reaulator, highpressure hose, and comnressed air tank were used. The scott backpack was not used because the straps interfered with chest electrodes. A Survivair backpack and harness were used, which did not interfere with ohest electrides. The refulator was mornted on the tank. Two 36-co (14.2-in.) jow-oressure hoses were jointd to make a hose long enough to connect the tank-mounted regulator to the facepiece. A calibrated thermistor thermometer was used to monitor the ternotrature of the inhaled air. (TINSP), in a copjer tet installed at the joint of the lod-pressure hoses, set Fig. 4. The factoiece used the pressurt-loaded exhalation valve for all 


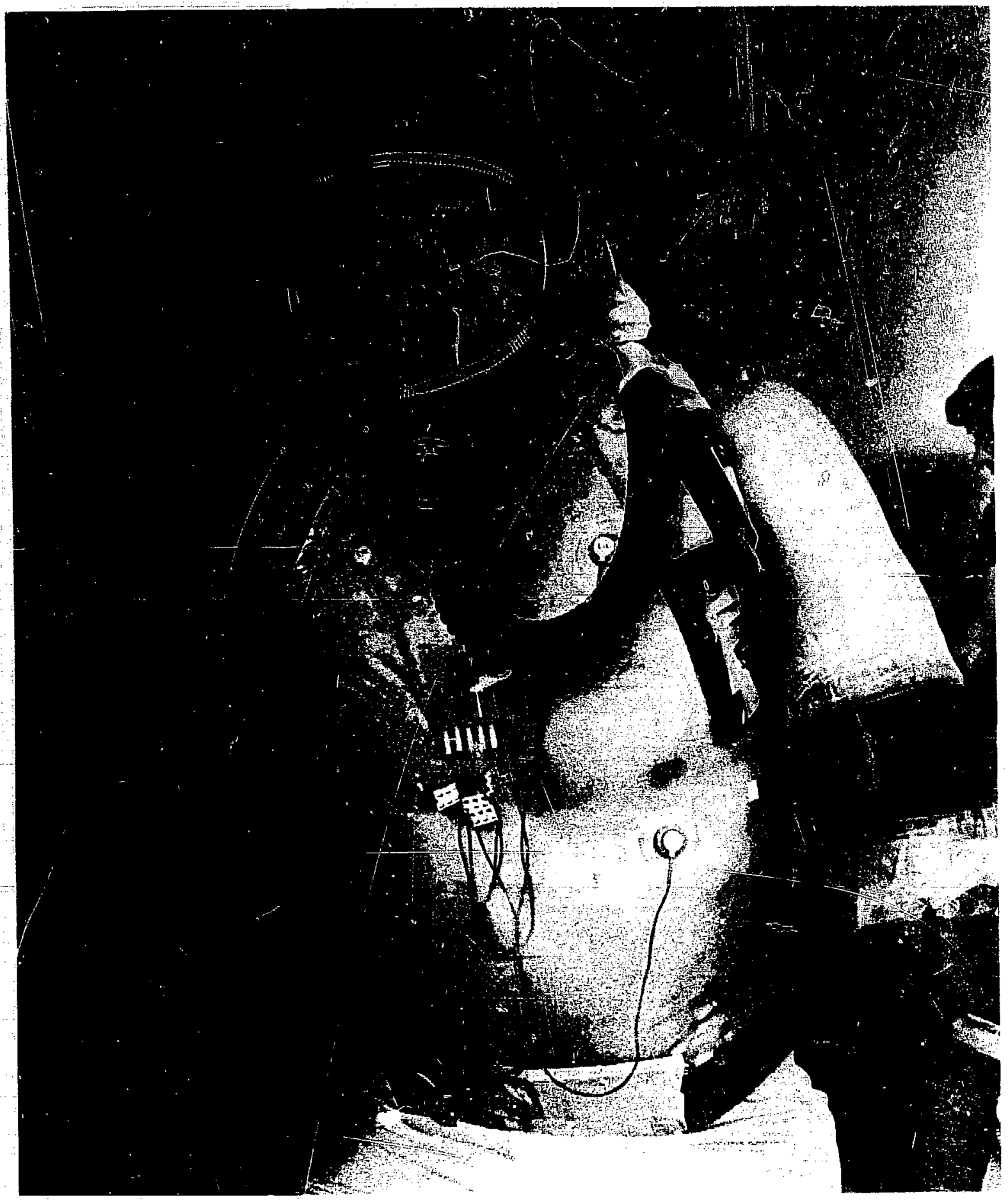

Fig. 3.

s:bject wearing test respirator, front view. 


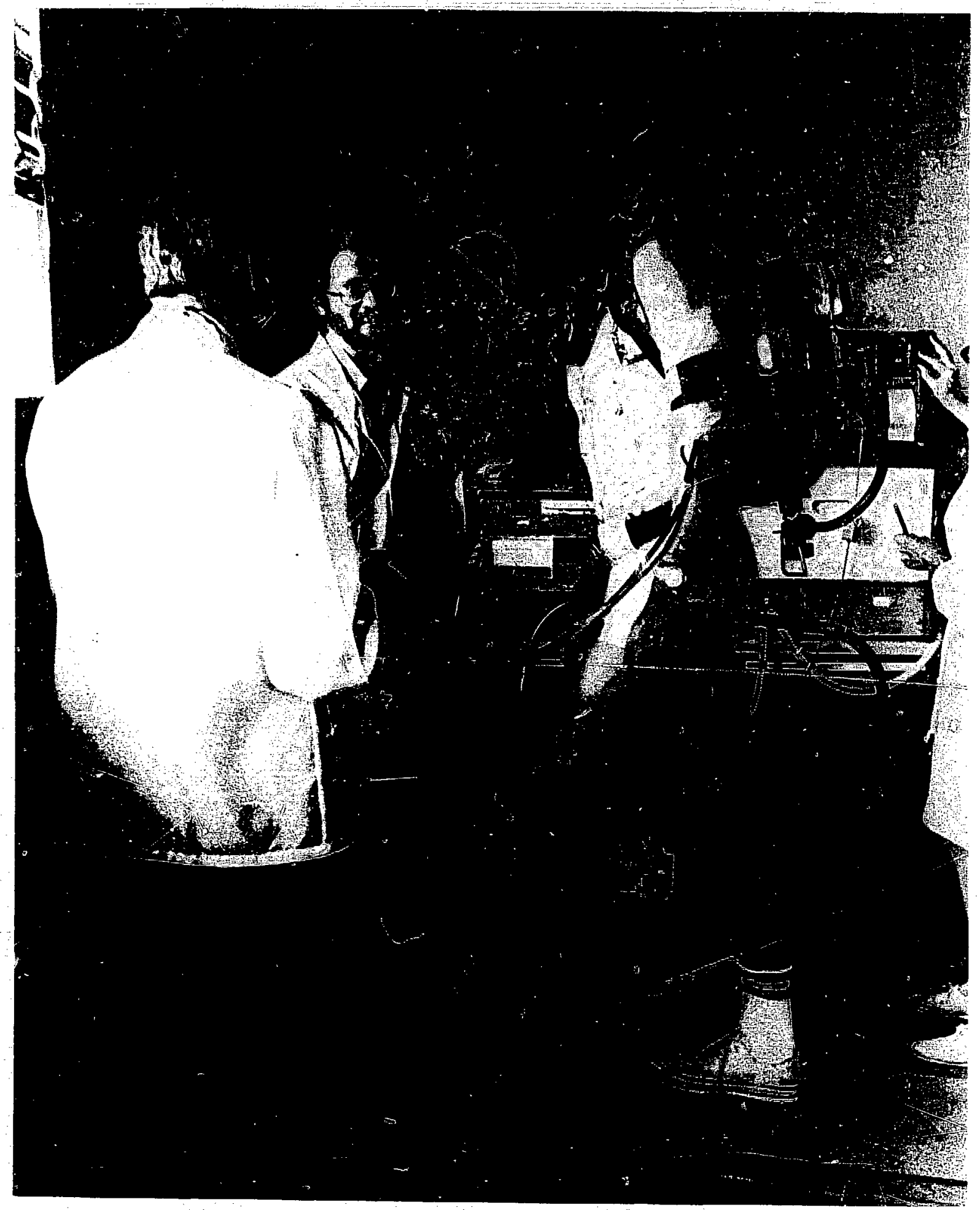

Fig. 4.

Subject wearing test respirator, side view, while on treadmill. 
tests because ERDA fire firhters are, in oentral, surilet with the pressure-loaded exhalation valve and a requlator which is switch-selectable for demand or pressure-demand mode. The oressure-loaded exhalation valve causes a lower exhalation resistance pressure in demand mode than in oressure-demand mode. The total weight of the test unit was 15.820 b. (3.4.9 ibs) with a charged (13.8 MPa) bottle. The difference in weikht between charged and discharged ( $4.1 \mathrm{MPa}$ ) bottles was $0.895 \mathrm{~kg}$ ( $1.97 \mathrm{lbs}$ ). Compressed air used to fild the bottles net grade E standards, 16 The decrease in pressure in the tank winch occurred during use caused the temoerature of the air in the tank to desteast, and, therefore to decrease the temperature of the inspired air (see II. E., Results).

LASL RRDS realized that the modificatiuns made the iest respirator an unapproved [by Mine Enforcement Safety

Adninistration - Nationai Institute of occunational Safety and Health, (MESA-NIOSH)] device. However, the purpuse of the studv was to pain basic data un the ohvsiobogic responst to wearing this class of device, and the individuais were not being exposet to contaminants. Therefore, the use of an aonroved devices was not necessary.

5. Statlstics. The extent to which the resoirator conditions (a) affected work duration and the cardiovascudar system for both smokers and non-smokers (b) was determined using a two-factor factorial analysis of variance ( $a$ $b$ ) with reneated neasures acruss respirator conditions. When a significant $\mathrm{r}$ interaction was found, differences within simoit main $\in f f \in c t s$ wert probed by a Newnan-Keuls post-hoc test to jetermine where significant ( $P<0.05)$ diffelences between neans existed. 17 In addition, differences between the smoker and non-smoker clinical screening data wert analyztj usin; a student t statistic.

\section{E. Resuits}

Tabie I gives some pertinent charactelistics of the two sroups of subjects. There was no significant difference in a height, weight, or measured pulmonary daraneters bet.uen smokers and non-smokers. Hence, differences observed in the results are not related to najor structurar differences of the two rouns.

Table II is a sumary of the data obtained. Totaj time un the treadmill was, statisticaliy, sianificantiy greater durins. test condition 1 (contrul, no weight, no facepiece) than for anv of the other three expeiimental conditions fur buth smokers and nun-smokers, set Fig 5. In addition, non-smukers jerformed un the treadmill for a longer period of time than the smokers. At the second and third stages of the treadmill protocol, the heart rate of the non-smokers was significantiy less during test condition 1 than during any other condition. This difference was not found for the smokers. The final stages of the treadnill protucol showed no significant effect on heart rate or bloud pressure for any test condition. Hence, calculated systolic index (systolic pressure $X$ heart rate) also was non-significant. 
TABLE I

SUBJECT CHARACTERISTICS

(Means \pm Standard error of the ineans)

\begin{tabular}{|c|c|c|c|c|c|c|}
\hline & & $\begin{array}{l}\text { Age } \\
\text { (yrs) }\end{array}$ & $\begin{array}{c}\mathrm{Ht} \\
(\mathrm{cm})\end{array}$ & $\begin{array}{l}W \mathrm{t} \\
(\mathrm{kg})\end{array}$ & $\begin{array}{c}\text { FVC } \\
\text { (i) } \\
\end{array}$ & $\begin{array}{r}\text { FEV }_{1.0} \\
-(\%) \\
\end{array}$ \\
\hline Nonsmokers & $s \bar{x}$ & 31.0 & 176.6 & 75.9 & 5.13 & 84.0 \\
\hline$(N=8)$ & $S E_{\bar{x}}$ & 2.0 & 3.9 & 3.7 & 0.3 & 2.3 \\
\hline Smokers & $\bar{x}$ & 30.3 & 173.1 & 71.7 & 4.90 & 83.1 \\
\hline$(N=7)$ & $S E_{\bar{x}}$ & 2.2 & 2.6 & 4.9 & 0.31 & 3.5 \\
\hline$t$ & & 0.26 & 0.78 & 1.00 & 0.558 & 0.22 \\
\hline $\mathbf{P}$ & & NS & NS & NS & NS & NS \\
\hline
\end{tabular}

with int excention of Tforte and TI there weris nu further significant diffelences ubstrvej across cunditions. Figut 6 presents the resounse of forehtad temperature to prozressive work and reouvery of buth grougs of subjects. TFure was significantly lowel during conditions 3 and 4 than during cunditions 1 and 2 for both smokers and non-smokels. There wele no tiffertnces in Trupt between conditions 3 and 4 , altrough the mean trend of conditiun 4 was ajways juwtr than condition 3 ; ste Fio. 6 . These respunses are related to the ororyessively decleasino insoired air temperaturt ubstrved threurhort the test; set Fig 6 . Insoired air temperatures decreased an averaze of 9.700 , with a standard Jeviation of 2,400 , dur ine the demand and Dressure-demand brtating cunditions ant this resulted in an average decrease of ?.50 C, with a standard deviation of $1.80 \mathrm{~g}$, in the measured Tfore. The inspired ail temoerature drosoed due to the continuaju decreasing olessure in the air tank.

The ejectrucardiurrabic recordings evidenced no remarkabje finfings, althuuph ninur alterations in patterns were observed turing the course of the test. There were only four instances where a series of premature ventricular contractions (Pro"s) were observed ard these appeared to be unrelated to sonditions or to smoking habits. Set labje III. A sunmary of the subjective cumments uffered by each subject at the end of each test is outlined in Tabie IV and nroves more informative with resject to the effect of the resoirator. In both conditions 1 and 2,1 e oains and reneral fatioue accuunted foi aij the leasons for stopping. However, in those cunditions where the face mask was being worn ( 3 and 4 ) other cunolaints bert lack of ail, claustruphobia, and excessive heat, in additisn to leg pain and rentral fatigue. 
AVERAGE GROUP DATA FOR EACH TREADMILL STAGE, MAXIMAL WORK AND RECOVERY DURING WORK UNDER THE FOUR RESPIRATOR CONDITIONS

(10\%, $1.7 \mathrm{mph}$ ) $2^{\prime} 30$ - 3' CO

\begin{tabular}{|c|c|c|c|c|c|c|c|c|c|}
\hline & & 1 & & & & 3 & & 4 & \\
\hline & & $\underline{s}$ & NS & $\underline{\mathbf{s}}$ & NS & $\underline{\mathbf{s}}$ & NS & $\underline{\mathbf{s}}$ & NS \\
\hline & HR (beats/min) & 105.9 & 104.4 & 110.6 & 108.8 & 112.6 & 110.5 & 117.4 & 110.8 \\
\hline & $\operatorname{SBP}(\mathrm{mm} \mathrm{Hg})$ & 134.7 & 138.8 & 129.5 & 139.5 & 132.6 & 137.5 & 13.5 & 146.1 \\
\hline & $\operatorname{MBP}(\mathrm{mm} \mathrm{Hg})$ & 99.4 & 100.8 & 93.1 & 102.1 & 95.9 & 99.2 & 97.0 & 105.6 \\
\hline (10\%, $1.7 \mathrm{mph})$ & $T_{\text {INSP }}\left({ }^{\circ} \mathrm{C}\right)$ & - & - & 一 & - & 19.2 & 18.0 & 18.4 & 18.1 \\
\hline $400-300$ & $T_{\text {FORE }}\left({ }^{\circ} \mathrm{C}\right)$ & 33.1 & 33.7 & 33.2 & 33.4 & 32.7 & 31.2 & 31.7 & 31.7 \\
\hline & Si $\left(10^{3}\right)$ & 14.2 & 14.5 & 14.3 & 15.2 & 14.9 & 15.2 & 15.8 & 16.2 \\
\hline & HR (boats/mın) & 131.0 & 121.9 & 139.0 & 133.3 & 142.4 & $\mathbf{1 3 8 . 5}$ & 150.9 & 137.3 \\
\hline & $58 P(\mathrm{~mm} \mathrm{Hg})$ & 150.3 & 149.8 & 140.9 & 157.5 & 150.7 & 158.1 & $16: .4$ & 162.9 \\
\hline Stage Two & $\operatorname{MBP}(\mathrm{mm} \mathrm{Hg})$ & 105.1 & 108.6 & 99.6 & 107.6 & 106.3 & 109.6 & 108.3 & 112.1 \\
\hline (12\%, $2.5 \mathrm{mph})$ & $T_{\text {INSP }}\left({ }^{\circ} \mathrm{C}\right)$ & - & - & - & - & 16.1 & 15.2 & 15.5 & 15.4 \\
\hline & $\left.T_{\text {FoRe }}{ }^{\circ} \mathrm{C}\right)$ & 33.1 & 33.6 & 33.1 & 33.2 & 32.2 & 30.6 & 31.6 & 31.2 \\
\hline & SI $\left(10^{3}\right)$ & 19.7 & 18.3 & 19.6 & 21.0 & 21.5 & 21.9 & 24.4 & 22.4 \\
\hline & HA (beats/min) & 171.0 & 160.8 & 179.3 & 174.6 & $177.2^{\circ}$ & $174.9^{+}$ & $181.4^{\circ}$ & 175.9 \\
\hline & $\operatorname{SBP}(\mathrm{mm} \mathrm{Hg})$ & 165.6 & 163.5 & 162.0 & 172.2 & $162.2^{*}$ & $177.6^{*}$ & $171.0^{*}$ & 176.0 \\
\hline Stage Thro & $\mathrm{M} \theta P(\mathrm{~mm} \mathrm{Hg})$ & 110.8 & 113.0 & 110.7 & 174.9 & $110.2^{*}$ & $118.8^{\circ}$ & $113.5^{*}$ & $\$ 18.2$ \\
\hline$(14 \%, 3.4 \mathrm{mph})$ & $\left.T_{\text {INSP }}{ }^{\circ} \mathrm{C}\right)$ & $\cdots$ & 一 & - & - & $11.9^{\circ}$ & $17.6^{+}$ & $11.1 *$ & 11.5 \\
\hline $050=000$ & $\left.T_{\text {FORE }}{ }^{\circ} \mathrm{C}\right)$ & 33.0 & 33.7 & 32.9 & 33.5 & $31.2 *$ & $29.0^{+}$ & $30.5^{*}$ & 30.1 \\
\hline & SI $\left(1 c^{3}\right)$ & 28.3 & 26.3 & 29.0 & 30.1 & 28.7 & $31.1^{+}$ & $31.0^{\circ}$ & 31.0 \\
\hline & TIME (sec) & 711.7 & 746.6 & 586.7 & 615.6 & 571.0 & 589.6 & 575.9 & 612.5 \\
\hline & HR (bedta/min) & 190.8 & 189.1 & 185.8 & 185.4 & 185.1 & 180.8 & 188.7 & 184.0 \\
\hline & $\operatorname{SBP}(\mathrm{mm} \mathrm{Hg})$ & 176.6 & 171.5 & 163.7 & 172.8 & 161.9 & 177.9 & 169.9 & 177.0 \\
\hline Maximum Values & $\operatorname{MBP}(\mathrm{mm} \mathrm{Hg)}$ & 100.8 & 902.1 & 99.3 & 105.6 & 99.4 & 96.0 & 95.9 & 97.0 \\
\hline & $T_{\text {INSP }}\left({ }^{\circ} \mathrm{C}\right)$ & - & - & - & - & 11.1 & 10.1 & 9.9 & 9.7 \\
\hline & $T_{\text {FORE }}\left({ }^{\circ} \mathrm{C}\right)$ & 32.8 & 34.0 & 32.7 & 33.6 & 27.7 & 29.2 & 29.9 & 29.2 \\
\hline & si $\left(10^{3}\right)$ & 33.7 & 32.4 & 30.4 & 32.0 & 30.0 & 32.2 & $32 . !$ & 32.6 \\
\hline & in & & & & & & & & \\
\hline
\end{tabular}


TABLE II (cantinued)

Fiecovery Data

CONDITIONS

Recuvery

min 1

Recovery

$\min 3$

Recovery

$\min 5$

\section{HA (baats/min)}

SBP (mm Hg)

MEP (mm Ha)

$T_{\text {INSP }}(\mathrm{C})$

TFORE ("C)

si $\left(10^{3}\right)$

HR (beats/nin)

$\operatorname{SEP}\{\mathrm{mm} \mathrm{H} \mathrm{g}\}$

MEP (mn Hig)

$T_{1}(\mathrm{C})$

$T_{\text {fore }}\left({ }^{\circ} \mathrm{C}\right)$

St $\left(10^{3}\right)$

Lactate $\left(\mathrm{mg} / \mathrm{cm}^{3}\right)$

$H R$ (beats/min)

SEP $(\mathrm{mm} \mathrm{Hg})$

$\operatorname{MBP}(\mathrm{mm} \mathrm{Hg})$

$T_{1}(" \mathrm{C})$

$T_{\text {FCFE }}\left({ }^{\prime} \mathrm{C}\right)$

Si $\left(10^{3}\right)$

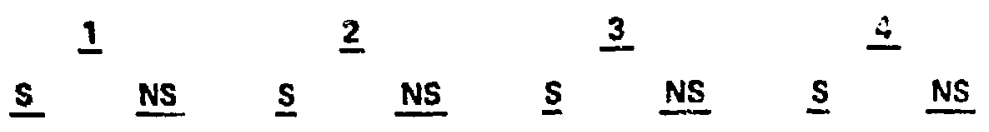

$\begin{array}{llllllll}163.7 & 168.4 & 164.7 & 166.9 & 170.8 & 163.3 & 169.7 & 157.6\end{array}$

$\begin{array}{llll}168.9 & 160.9 & 149.7 & 160.9\end{array}$

$\begin{array}{llll}165.1 & 167.5 & 174.7 & 169.9\end{array}$

$\begin{array}{llllllll}112.9 & 110.6 & 95.1 & 106.8 & 109.1 & 114.1 & 109.6 & 116.3\end{array}$

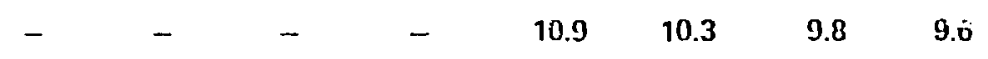

$\begin{array}{llllllll}32.9 & 34.1 & 32.6 & 33.9 & 30.4 & 29.5 & 29.5 & 29.5\end{array}$

$\begin{array}{llllllll}27.6 & 27.1 & 24.7 & 26.9 & 28.2 & 27.4 & 23.6 & 28.5\end{array}$

$\begin{array}{llllllll}132.4 & 134.3 & 133.4 & 131.9 & 132.3 & 129.3 & 132.8 & 133.4\end{array}$

$\begin{array}{lllllllll}155.4 & 156.5 & 145.1 & 156.6 & 153.0 & 160.9 & 157.7 & 162.4\end{array}$

$\begin{array}{llllllll}106.1 & 107.0 & 109.9 & 104.8 & 105.7 & 112.6 & 107.6 & \mathbf{1 1 4 . 9}\end{array}$

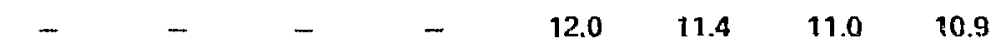

$\begin{array}{llllllll}33.4 & 34.5 & 32.6 & 34.1 & 31.2 & 30.6 & 30.3 & 30.7\end{array}$

$\begin{array}{llllllll}20.6 & 21.0 & 19.4 & 20.7 & 30.2 & 20.8 & 20.9 & 21.7\end{array}$

$\begin{array}{llllllll}78.0 & 68.5 & 68.4 & 74.0 & 60.8 & 60.6 & 61.5 & 71.9\end{array}$

$\begin{array}{llllllll}119.3 & 117.9 & 118.3 & 121.6 & 120.6 & \$ 14.9 & 121.3 & 121.1\end{array}$

$\begin{array}{llllllll}132.3 & 136.4 & 124.7 & 135.0 & 133.6 & 136.5 & 125.4 & 139.5\end{array}$

$\begin{array}{llllllll}92.1 & 97.4 & 91.9 & 96.1 & 99.7 & 101.6 & 93.6 & 101.3\end{array}$

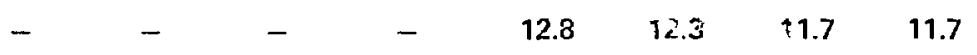

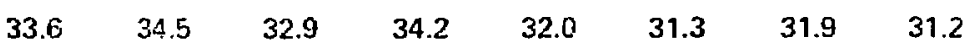

$\begin{array}{llllllll}15.8 & 15.8 & 14.8 & 16.4 & 16.7 & 15.7 & 15.2 & 16.9\end{array}$

F. Discussion

It is evident from the data that wearing the SCBA apdaratus significantly reduced the total time on the treadmill (maximal work oerformance) of the fire fighters. The reductions were $17.5 \%, 21 \%$, ard $18.5 \%$ for conditions 2,3 , and 4, respectivedy, regardless of smoking habits. Surprisingly, there wert no significant decrements in verformance due to the breathing mode utilized (condition 3 or 4) while wearing the mask, although the wearing of the mask resulted in a far greater degree or subjective discumfort. obviously, work performance was primarily related to the weight. of the SCBA. Decreases in work Derfornance have previuusly been revorted 18,19 and, in agreenent with our findings, 


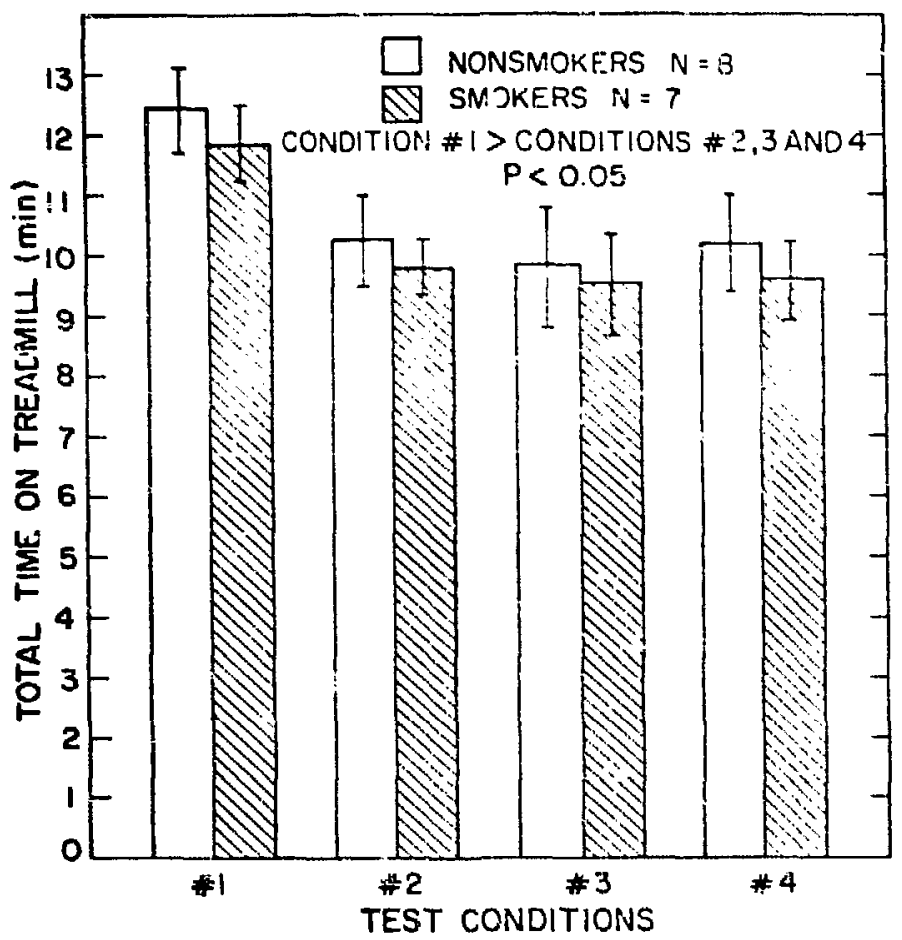

Fig. 5.

Total time on treadmill vs. test condition for all subjects.

have related the decrement to the additional weight of the firefighting equipment.

Invesigations into simpie air-purifyinr resnirators have documented significant decrements in maximaj work oer rormance regardiess of the physical fitness of the subjects. ?0, 2. As this type of resoirator adds minimal loads to the subject, it was concluded that increased respiratory burden was the orimarr cause of a decreased maximal work derformance. However, in an extensive investigation of four tyoes of air purifving resoirators durin? submaximal performance $\{10 \mathrm{~min}$ work at $50 \%$ of maximal work capacity) Chatterjee2? was uanable to observe any sipnificant change in heart rate response due to the wearing of the nasks. This lack of effect way be related to the low work loads bein tr used which resulted in a ninimal increase in resoiratory work. During the present study, non-smokers had lower heart rates during non-weight-bearing conditions (condition 1) than during conditions 2, 3, and 4 at both the 2nd and $3 r d$ stages of the Bruce treadnil 1 test. However, wearing the mask did not affect the heart rate during exercise. Yet, the inciusion of subjective responses concerning the mask implicates the increased respiratory burden as one reasun for decreased work nerformance. Aithough not statistically significant, the mean decrement in Derformance and the greatest number of complaints concerning air suppiy were ubserved during condition 3 , or when the subjects were using 


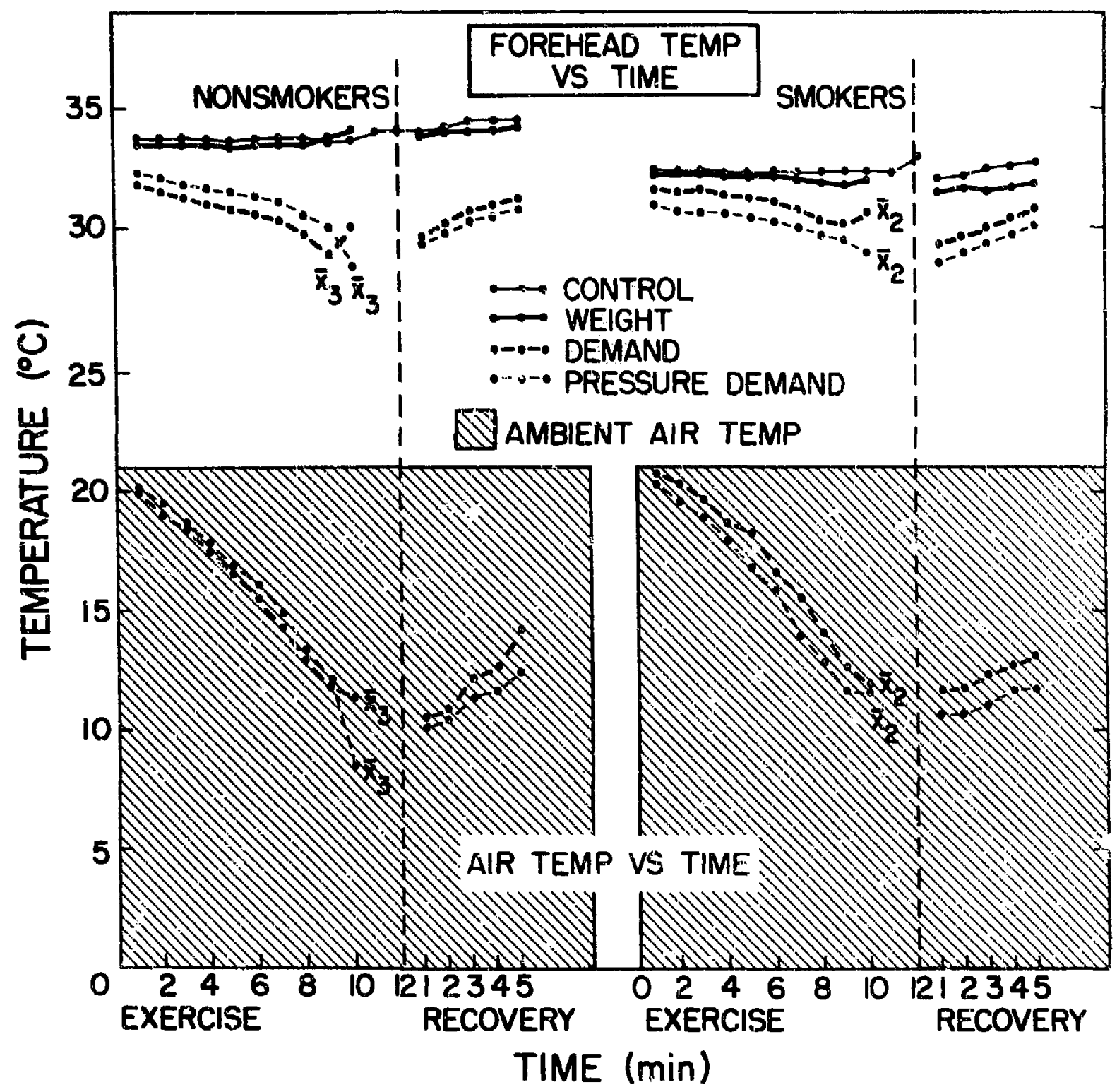

Fig. 6.

Forehead and air temperatures vs. time. $\bar{x}_{n}$ is the average for $n$ subjects.

demand rude. These cumbiaints wert not apparent during oressure-denand node even thourh the number of ciaustrophobic responses were the sane for both conditions. Hence, it could be implied that the increase in respiratorv work ( respiring against an atded insoired resistance) was a factur in the decreased work performance. Recentiy, this has beten subjected to a areful investication utilizing subjeciive and objective analvsis of various cumbinations of inspirej and exolred resistance. ${ }^{2}$ It was 
TABLE III

ELECTROCARDIOGRAPHIC FINCINGS FOR ALL CONDITIONS AND BOTH GROUPS OF SUBJECTS

Conditions

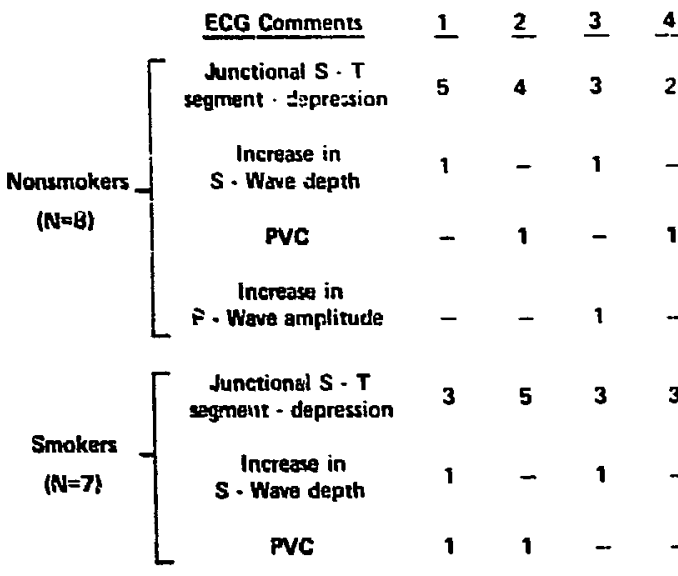

- The number in each block represents the number af changes within each condition for a specific group of subjects. e.g. 5 nonsmokers out of 8 had Junctional S - T segment - depression
TABLE IV

SUBJECTIVE COMMENTS REPORTED AS REASONS FOR TERMINATIDN OF EXERCISE

Canditions

$\begin{array}{ccccc}\text { Comments } & 1 & 2 & 3 & 4 \\ \text { Leg Pain } & 11 & 14 & 8 & 7 \\ \text { General Fatigue } & 4 & 1 & 2 & 4 \\ \text { Lack of Air } & - & - & 8 & - \\ \text { Claustrophobia } & - & - & 4 & 4 \\ \text { Hot Mask } & - & - & 1 & 1 \\ \text { Expired Resistance High } & - & - & - & 1 \\ \text { Dry Thruat } & - & - & - & i \\ \text { Total } & 15 & 15 & 23 & 18 \\ & & & & \end{array}$

found that subject discumfort was minimal when the pressure across the apdaratus was $l \in s s$ than $17 \mathrm{~cm} 420$ and the expiratory resistanae was very low. However, it was further observed that excessive resistance exerted turing inspiration was a major factur in determining, subjective tolerance. Unfurtunately, our data jo not allow us to conclude that inspired resistanoe was too hioh during inspiration on demand mode even thourh subjectiveiy the demand mode provided the most discomfort.

It may be bostulated from the subjective resounses that the Derformance of the demand valve is a factor of discumfort and physical limitation to the wearer durirg heavv work. Government regulations $2 \overline{3}$ only require the valve to be able to deliver 200 iiter/min flow and, while the manufacturers have generaliy sunojied vaives capabie of deiivering 400 - 450 ijter/min flow, it has betn observed that peak respiratory flow rates during maximal work may exeeed 720 liter/min. Therefore, part of the explanation of mask limitation during hard work may be related to the inability of the resulator valve to sunply sufficient air within a riven

respiratory cycie. This needs further investigation.

In the oresent study a significant surface cooling effect was ubserved during the wearing of the face mask. It was also noted that as the work load increased the inspired ventilation volumes increased, and consequentiy, the TI decreased. As the insoired air is cilculated within the mask, the cooler air, a maximum of $190 \mathrm{C}$ cooler than TFore, caused a $2.5^{\prime \prime C}$ drop in TFore. This coosino effect is benefical to the SCBA wearer as it helps to remove excess heat senerated by the increase in metabolic rate. "lore 
importantly, it has been previously shown during thermal stress that when $\mathrm{T}_{\text {INSP }}$ is greater than core temperature the capability to perform work is significantly reduced.3,24-26 one of the major findings in previous evaluations of four types of SCBA apparatus for mine rescue work was that the apoaratus that provided iowest TIJSP pluvided Ereater tojerance to work in heat and also imploved subject comfort. 24 Henze, the Scha used in this study wuudd be of benefit to a fire fighter expesed to high-heat loads during heavy work.

One further comment concerning the operation ui the Scutt-Air Pak SCBA netds to be made. The anjaratus used in the irvestigation when fully charged to $13.8 \mathrm{MPa}$ is rated as providing sufficient air for $30 \mathrm{~min}$ of operation. Yet following 10 min of treadmill walking to maximal levels and a subsequent 5 min of recovery, the air remaining registered $4.1 \mathrm{MPa}$, enough for a further 5 min of operation. In many cases firemen are required to work at high workloads for long otriods of time, $15 \mathrm{~min}$ or more, and under these cunditions, the ? $0-$ minute tanks may not Drovite a sufficient anount of air. The dractice of using unly 15-min aif tanks for buth econumy ant weight reductiun purpuses nay prove fatal to the fire fiohter. However, reariless of speculations, it woujd appear that it is imperative that the weight of the aonaiatus be roduced to a jevel whereby the maximal efficiency of the oderatur is not reduced, and that in situations of hirh work luad, suficient amuunts of air be nade availabit for more than $15 \mathrm{~min}$. Alsu, we feel that a serious iinitation exists with respect to the rejulator vaive and that thare is a net for further evaluztion of the valve during high work loass.

\section{i. Recummendations}

le lecommend that a physiolorical study tvaluate the effects of wearing an upen-circuit SCEA Juring strenuous exercise, concentrating on puimunary paraneters. Such a study should incurpolate bench tests of available regulators to determine air. flow characteristics. The two ohases of testing should be compared in order to determine whether available rezulators Jeiiver adequate air fiow rates to the wearer at all times. Manufacturers of this tyoe of device should be invited to observe and participate in such a stujy to insure their accediance of the results. ERDA may want to set oerformance standards from the results of $s u \approx h$ a study.

While not a goal of this project, the literature review and our own findings indicate that fire fighters as a group have a higher-than-normal incidence of cardiovascular disease.6-10 be recommend that ERDA consider including maximal stress tests in ERDA fire-fighter annual ohysicals. Further, ERDA should consider sounsuring physical conditioning programs during working hours for fire fighters.

One comment from a subject was that participating in the Fy 1976 studv, during which he had to reach maximal exertion and then $r \in c o v e r$ while wearing the resoirator, gave him a great deal more confidence in the device than regular training had provided. We 
recumnend that SC3A training orortams inclute laving the tiairet strenuuusly extreise and recuver white wearing the device.

The subjects al 1 commented that the Survivair harness uset in the study was more comfortable and allowed more movement than the Sout harness. Aiso, mudifications were mate to the Survivair

harness fasteners which, if the wearer were incapable of removing the device, aliowed anuther man to remuve the device from the wearer in a mattel of seconds. Eecause of the incleased acceptance and safety of the developed harness, we recomnent continusd work thetween LASL RRDS and the FrDA Lus Alanos Fire Dedartment to compare the develodet harness with existing harnesses.

\section{ACKNJWLEDGMEITS}

The authors would like to thank the foljomi neodie for their help on this study:

D. Hahn, Assistant Fire Chitf, and H. Richardsen ant S. Gonzales, Platoun Chiefs, for their cunstant assistance in setting-uo and scheduiing the testing ourtion of this nioject.

The nurses and lab technicians wo susported the testin? Doxtion of the project with dedication and sunerior quality work.

The fire fighter volunteers who, for science, went throurh difficult physical testing and maintained hioh intelest and enthusiasm.

II. TRAINIAG VIDEO TAPES - by T. C. Davis

LASL RFDS produced one training video tane for DSSC during Fy 1975. The title of the tade is "Dotration and Use of $\mathrm{Air}$. Purifying Respiraturs as Protection Arainst Airburne Raticartive Materials". The tape was made by Sandia Laboraturies Vifeo Services Division. The tape is in color, bruadcast auaitiv, ant professionaliy narrated. A copy of the tzoe, and a tyot cupv of the video tape narration, with notes, was deivered to the FrnA coordinator in January 1976.

III. DSSC RESPIRATOR MANUAL - by D. D. DOUTIaS

In FY 1975, plans were made to provide DSSC with a pesniratur. Manual which could be used to assist ERDA contractors in aumblying with ERDA requlations concerning the use of resoiraturs. This was necessary for two reasuns; ERDA contracturs art among the larrest users of respirators in the United States, and the existing regulations are contained in generalized form in the Anerican National Standards Institute (ANSI) document "Practices for. Respiratory Protection," ANSI Z88.2. The initial draft for ERDA"s 
manual was comoleted during 1975 , and extensive editing was done during FY 1976. In Fy 1976 ine nanuad was Dublished as report La$6370-4$.

ANSI Z38.2 Druvides basic information un respiratury prutection, howsver, it is difficult to detrrmine anolication of these standards to specific situations. The DSSC respiratur. ranuzi provides bacic policv infornation concerning the use uf resniraturs. It stresses the necessary ingredients for an acceptable resniratury nrotection orugran and discusses, in detail, how to met the various required elements of a resoirator orutection nrugran. It discusses why respiraturs are acceptable for some hazards and not accestable for others. The respirator. ustr is warred that a comnitet understanding of the airbornt concentratiuns of toxic materiajs within the wurk $\rightarrow$ lace and their teiationship to permissible leveis 27,28 is necessarv.

Complete discussions of the advantages and disadvantages of various resniratur types which nay be uset art given. Such informatiun is not inciuded in ANSI Z38.?. Infurmation is also inciuded on the NIOSH Resoirator AJproval System, sinet ERDA nui requires the use of NInSH-apruved resDiratory equidment unless sotciai circunstances dictate otherwise. The resoirator selection ruide riven in $238 . ?$ is expanted to include resoirator protection facturs (PFs). The use of PFs, which have betn developed at LASL over the Dast few vears, is exniained. In this refard, detaided infurmaicu is eiven concerning the tstabishnent of a guantitative man-testin DroTran to enabit EP. contracturs to utilize a quantitative fitting orojran. Methous of fitting lespiraturs on the jub are detaijed and the methods necessary to maintain a proper respiratury protection prorran are spejlet out.

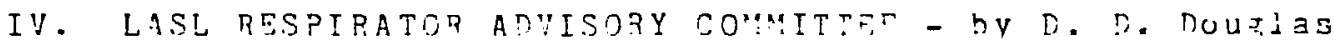

The LASL qesniratur. Advisurv Comittet was furmed at the lequest of FRTA, CSSC, to revitw soecial resoil gtorv nrotective Droblems wich ale uniaut to ERD? contrastors and mav leadirt the use of equionent that is not adoluved bv the lingli Testing Certification Braneh (TCR). The cumittet is cumoused of Dersuns with outstanding quaifications in the arta of lesoiratory plutection. (Ste ADdendix 5 ).

The cumitite $n \in t$ unce this year to sonsider the testing of the Savannah River Suit, which is an ailiant suit that ihe DuPunt Savannah River Project uses. The committee reviewed the LASL RRDS test report and determined it would not be advisable to approve this suit for the following reasons:

1. The hose used ror the Savannah River Suit was not sufficientiy strung to withstand the oressure test requiper. 2. The suit could aobieve a PF of oyel 10 ojo oniy if a variety of precautionary neasurements were taken. The comrittet feit the precautionary ineasurenents were too ejaborate to be disigently fujduwed by all eroluves. 
3. The committe did not know the PF required for this aopication of supplied air suits. The committee asket that in the future, work site information be nresented alon? with the suit test report so that they could determine whether the suit was adequate for the task.

The cummittee charter was reviewed bv Frof Headruarters, who tetermined that the charter was more elaborate than necessary. It was revised. A copy of the revision is incluted in anaentix $C$. The document simolifies the comittee dutits ant is mort anderstandable.

\section{REFERENCES}

1. Respiratory Protective Devices Manual (American Industrial Hygiene Association and the American Conference of Governmental Industrial Hygienists, 1963), DD. 9-17.

2. Bentley, R. A., "Acceptable Levels for Breathing Resistance of Respiratory Apparatus, "Arch. Environ. Health 27, $273-$ $280(1973)$.

3. Lind, A. P., "The Infiutnat of Insoired Air Temnerature un Tulerance to Work in the Heat," Prit. J. Injustr. Met.' 1?, $126-130(1955)$.

4. Blockley, W. V., "Changes in the Boundarv Betuten Neutraj and Stressful Thermal Conditiuns Caused by Resoiraturv Prutective Equionent," bebb Assuciates Redurt (1วf.4).

5. Seiig, van R., i. Manriein, and P. Schettler, "ner Finflub von Staubschutzmasken aus dit Leistungsfahimkeit des Berpmannes," Atenschuzz-Int. 12, 25-29 (1073).

5. Sidur, R., and J. 3. Peters, "Fire Fightino and pudmunary Function," An. Rev. Reso. Nis. 102, 249-254 (1974).

7. Sidur, R., and J. l.. Peters, "Prevajence Rates of Chrunic Non-Sotcific Resdiratory Disezse in Fire Fighters, "Am. Rev. Resp. Dis. 102, 255-261 (1974).

8. Peters, J. A., G. P. Theriault, L. J. Fint, and D. H. Vegman, "Chronic Effect of Fire Fightin: un Pujmonary Funation," J. Msd. 201, 12?n-12?? (1974).

9. Barnard, R. J., and W. W. Duncan, "Heart Rate and Electrocardiographic Responses of Fire Fighters," J. Occup. Med. 17, 274 (1975).

10. Barnard, R. J., G. W. Gardner, N, V. Diaco, and Raltus, "Near Maximal ECG Stress Testing and CHD Risk Factor 
4razysis in Lus Ancties Cisv Firentn," J. Jacus. "Et. 17, 6az $(1 \cap 75)$.

11. Eluce, R. A., "syelcise Testint of Patients with Goronary Disease," Anna Ci in. Res. ㄱ. ?? ? (1071).

3. Dubin, D., "Fasic Princzoles," in Ranid Interpretation uf Oyjo (cuver pubishing co, Fia., 1975 ), pp. 1-43.

13. Fuisuck, $\because$ L., Buhannon, R. L., Couper, K. H., Avres, J. J., latd, A., White, S. R., Linnerud, A. C., "4

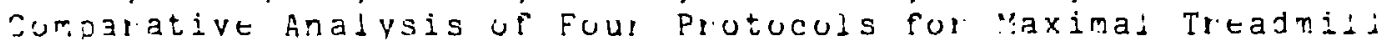
Stiess Tests," An. Heart J., Vuj. 02, oD. 30-46, July 9976.

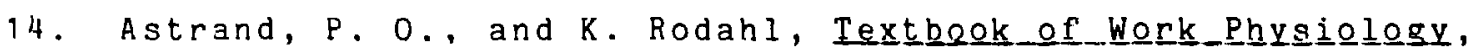
(MeGraw-Hill Book Co., N. Y., 1970), D. 573 .

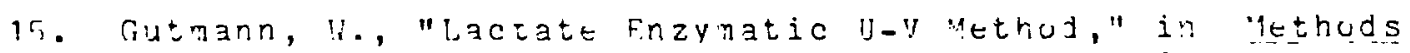
of Inzvmatic Anajysis, i. U. nerztever, td., (Asajemic press, Hew Yulk, 1974), כ. 1484.

16. American Vationai Staniard Institute oanohiet G-7.1., 295.1-197?, "Cummulty soteificatiun fur Air," Cumnitssed $6 a s$ Assuciatiun, Ina., litw York, i. Y., 1073.

17. Wintr, B. J., Stat sticai Principles in Experimentaj Desirn, (lcaraw-yild aook Co., M.Y., 1962) po. 20a and 31 .

18. Davis, P. O. and D. Laine Santa Maria, "ouantifving the Hunan Energv Custs: A Laboraturv Fxperiment, "Maryiand Fire and Rescue ruldetin 业, $1(1975)$.

19. Duncan, ". W., G. I. Gardner, and R. J. Barnard, "Dhysiulurical Resnunses of Men Working in Fire Fighting Equinment in the Heat,"

let. Sc. Soorts $1,54(1076)$.

20. Van Huss, W. D., F. Hartman, F. N. Craig, and A. H. Steinhaus, "Resniraturv Eurden of the Field Protective $4 a s k$ Unjer Fxercise Luad," Fef. Proc. (Abst. 26́,721 (1975).

21. Martin, De V. H., "The Effect of Trajning and a Mask on the Voluatarv Endurance Time of Men Exercising in the Heat," J. Physiul. (Lund) 229, ?00, (1072).

2?. Chatterjet, S. K. "Heart-rate Resounse to Wearing Industrial Protective Face Mask Jnder Variable Work Conditions." Indust. Hed. 38:356, 1976.

23. Federa: Register, zoCFR11.

24. McCutchan, J. N., and C. K. Taylor, "Resoiratury Heat Exchanse with Varying Temoeraturt and Hunidity of inspirted Air," J. ADol. Physiol. 4, 121 (1951). 
25. Martin, De V. H., and S. Callaway, "An Evaluation

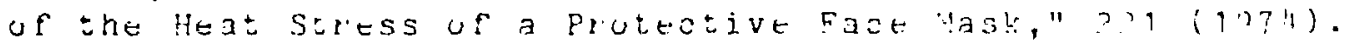

25. Lawitnat, 5 . and $\mathrm{D}$. Leyin. "The Infjuenet of Resnifitia

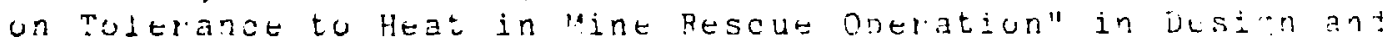
Use of Resoirators, C. N. Davies, ed., (Pengamon Press Book, MacMillan Co., New York, 1962) 105, p. i.

27. American Conference of Govelrinent Industrial Hygienists, "Threshold Limis Values for 1975," ACGIH, 1014 Broadway, Cincinnati, OH.

28. Nationai Council on Radiation Protection and Measurements, "Maximum Permissible Body Burdens and Maximum Permissible Concentrations of Radionuclides in Air and Water for Occupational Exposures," NBS Handbook 69 (National Bureau of Standards, 1959; published with addendum I, 1963).

\section{APPENDIX A}

UNIVERSITY OF CALIFORNIA CONSENT TO ACT AS HUMAN SUBJECT

(Regular Form No. 2)

SUBJECT'S NAME: - DATE :

1. I hereby authorize C. L. Shafer, M.D. and Thomas Davis (principal investigators) and such assistants as may be designated by them to perforni upon (subject) treadmill stress testing

which shall consist of the following:

As a prospective test subject I understand that I will undergo a thorough medical screening procedure prior to any experimental sessions. This screening exanination requires a medical questionnaire, along with a personal interview and physical examination conducted by a physician, urinalysis, blood tests, chest $x$-ray, clinical lung function tests and a resting 12-lead electrocardiogram. If my general health is found to be good, and if the resting 12-lead ECG is within normal limits, I will then undergo a volitional maximal exercise stress test on a motor driven treadmill. The period of physical exertion during the actual stress test usually requires about 10 minutes. Multilead electrocardiographic tracings, heart rate, systolic and diastolic blood pressure, forehead skin temperature will be obtained immediately prior to the stress test and at each progressive stage of work (three minute intervals) throlighout the 
ill 1.il struss tust. A V'5 ECr will be monitored continuously on an oscilloscope and recorded fir 10 sicunds at each minute of the test on paper tape. Only if : am still fount to be in good general health and free of evidence of disorders "t the heart, lung's and blood vessels - both before and after exercise - will I be accepted into the subject pool.

Following acceptance to the program I will undergo one or more practice sessions thought necessary for me to become accustomed to wearing the respirator while walking or running on the treadmil1. After these practice sessions I will participate in three experimental exposure conditions. Each exposure condition will be separated by one week or more. The conditions require that I carry out the exact same stress test protocol as described avove while wearing the Scott Air Pak respirator, with and without face mask and during demand and forced pressure breathing. (The respirators used in this study are those usually worn by fire fighters during fire figuting procedures. As the subject pool consists mainly of firemen the respirator should not prove to be disturbing to the subject, especially foliowing the practice sessions.)

I will report by appointment for the experimental sessions:

a) At the same time of day following a minimum of five hours without food and drink, and twelve hours without smoking.

b) I will be dressed in T-shirt, shorts and supporter, socks and tennis shoes.

c) As heat dissipation is a factor in this study I will dress in the same clothes for each test.

d) At three to four minutes following each stress test, a three milliliter recovery venous blood sample will be taken via vena puncture from my antecubital vein.

2. The foregoing procedure(s) and/or investigation(s) has (have) bren explained to me by C. L. Shafer, M.D. and Thomas Davis

\section{Name}

3. I further understand and have had explained to me by C. L. Shafer, M.D.

and Thomas Davis that the following discomforts and risks may be involved in the stress testing procedure, such as: general fatigue, leg fatigue, leg pains or cramps, shortness of breath, sweating, nausea, fainting, chest pain, adverse blood pressure or heart rate response, developinent of heart rhythm irregularity or disturbance, development of abnormal ECG response and, finally, the remote possibility of sustaining a heart attack during or immediately following the procedure.

4. I understand that the potential benefits of the procedure are as follows:

a) This study is believed to be beneficial in that a physiological and clinical determination of the respirator imposed stress on a human will be evaluated. 
b) There will be an explanation to me, the test subject, nf my com?lete examination and all of my tests and the conclusions that wiil be reached therefrom, i.e., a scientific assessment of my physiological working capacity and a critical appraisal of my cardiac, pulmonary and circulatory functions.

5. I understand that C. L. Shafer, M.D. and

Thomas Davis (principal investigators)

and such assistants as may be selected by them will answer any inquiries that I may have at any time concerning the procedure.

6. Finally, I understand that I may terminate my participation in this study at any time, and that owing to the scientific nature of the study, the principal investigators named herein may in their absolute discretion terminate my participation at any time. I further understand that my records will be held in strict confidence from non-medical people (such as employer, insurance agents, etc.) until my additional consent or the consent of legal representative of myself or my estate is obtained to release such information unless such information includes any unusual physiological symptoms or findings that might endanger my life and healih in connection with my cmployment. In the event I am placed in such a position, the principal investigators named hereiñ shall, by virtue of my signature hereto, have my consent to release said information to my employer and personal physician for evaluation by them.

7. By signature hereto I acknowledge that I have read and had $\mathrm{fu}_{\perp}^{2} \mathrm{y}$ explained to me by

C. L. Shafer, M.D. and Thomas Davis

and that I fully funderstand all of the above, including the risks and benefits to me associated with the treadmill exercise test, both without and incorporated with the wearing of the respirator in the three experimental exposure conditions.

Subject

Witness

Date 
LGS ALAMOS RESPIRATOR ADVISORY COMMITTEE

Jerrold L. Caplan, Health Physicist Occupational Health Stardards Branch Office of Standards Development U.S. Nurlear Regulatory Commission Washington, DC 20555

Darrel D. Douglas, Section Leadeı Re:pirator Research and Divolupment Sectiou Industrial Hygiene Group, MS 986 Los Alamos Scientific Laboratory P.0. Box 1663

Los Alamos, New Mexico 87544

Edwin C. Hyatt Industrial Hygiene Consultant 545 Rover Boulevard, White Rock Los Alamos, New Mexico 87544

Edwin J. Kloos Respiratory Protective Devices Officer Mining Enforcement and Safety Administration

U.S. Department of Interior 4800 Forbes Avenue

Pittsburgh, Pennsylvania 15213

Joseph Lipera, Group Leader

Industrial Hygiene \& Toxicology Group Hazards Control Department, L-519

Lawrence Livermore Laboratory P.0. Box 808

Livermors, California 94550
John P. O'Neill, Senior Scientist.

office of Health Standards Development Occupational Safety and Health

Administration

U.S. Department of Labor

Washington, DC, 20210

Walter E. Ruch

Regional Program Director, Region X

National Institute for Occupational Safety \& Health

U.S. Department of Health, Education, and Welfare

1321 Second Avenue

Seattle, Washington 98010

Robert H. Schutz, Director

Test \& Certification Laboratory NIOSH ACOSH

U.S. Department of Health, Education, and Welfare

944 Chestnut Ridge Road

Morgantown, West Virginia 26505

Charles J. Shoemaker, Director

Respirator Section, Physical

Protection Laboratory

Defense Systems Command

U.S. Department of the Army

Edgewood Arsenal, Maryland 21010

John M. White, Health Physicist

General Services Division

Chalk River Nuclear Laboratory

Atomic Energy of Canada, I,imited

Chalk River, Ontario

Canada 


\section{APPENDIX C}

\section{LOS ALAMGS SCIENITIFIC LABORATORY RESPIKATOR ADVISORY COMMITTEE}

RESPONSIBILITIES, ORGANIZATION, PROCEDURES

\section{SCOPE}

A. The purpose of the Los Alamos Scientific Laboratory (LASL) Respirator Advisory Committee is to review, evaluate, formulate conclusions, and make recommendations concerning (1) the adequacy of test procedures and test criteria for respiratory protective equipment needed by Energy Research and Development Administration (ERDA) contraccors, (2) the adequacy of the performance of respiratory protective aquipinent needed by ERDA contractors, and (3) other activities as requested by ERDA, Division of Operational Safety, Health Protection Branch.

B. The LASL Respirator Advisory Committee will advise the LASL Industrial Hygiene Group, Respirator Research and Development Section, which, in turn, wi11 make recommendations to the ERDA Division of Operational Safety, Health protection Branch (OS) which will make all final decisions.

\section{COMMTTTEE MEMBERSHIP}

The committee membership shall be selected from persons knowledgeable in the field of respiratory protective equipment. A balance of members from federal agencies, Industry, consultants, labor, etc., should be selected. Comittee size shall be determined by OS. The Chairman and the Secretary shall be from the Respirator Research and Development Section and OS, respectively. These members shall be nonvoting members of the committee.

\section{APPOINTMENTS TO COMMITTEE MEMBERSHTP}

A. Appointments to membership on the committee are made by the Chairman with the concurrence of $O S$.

B. Earh committee memher will be appointed for a period of three years with reappointments possible for a maximum of one additional period of three years for a maximum period of committee membership of six consecutive years. If a commitcee member resigns or if he fails to attend two consecutive meetirgs, a new committee member will be appointed to replace this person.

\section{SPËCIFIC RESPONSIBILITIES}

A. Chairman

1. Makes arrangenents for meetings of the Respir.tory Advisory Committee, prepares agenda for meetings, and keeps members of committee informed of these plans.

2. Notifies committee members of dates and locations for meetings at least 30 days before the meeting date.

3. Dirscts the proceedings at committee meetings. 
4. Solicits views of committee members, determines consensus of: committee members on said subjects, and consolidates consensus recommerdations made $r$, committee members into an advisory report to the Respirator Research and Development Section.

B. Secretary

1. Keeps records of meetings of Respirator Advisory Committee.

2. Distributes copies of minutes of rommittee meetings to all committee members.

C. Comittee Members

to:

Review, evaluate, and make comclusions and recommendations relative

1. the responsibilities, organization, and procedures of the Respirator Advisory Committee;

2. procedires to be utilized in testing the performance of special respiratory protective equipment needed by ERDA contractors, and the performance criteria for said equipment;

3. the performance of special respiratory protective equipment needed by ERDA contractors.

V. OPERATING PROCEDURES

A. A quorum for a meeting of the Respirator Advisory Committee shall be five of the voting members of the committee.

B. Conclusions and recommendations made at a comittee meeting or maje by written communications between committee members and the Chairman must be agreed to by four of the voting members.

C. Review and Evaluation of Respiratory Protective Equipment

Interpretations of eligibility for testing shall be subnitted direct $1 \mathrm{y}$ to $\mathrm{OS}$.

1. The Respirator Research and Development Section shall perform the necessary equipment tests according to procedures established by the -ommittee and shall compare the test results with test criteria established by the committee. The Respilator Research and Development Section shall formulate conclusions and recommendations relative to the adequacy of the performance of the equipment, shall write a report containing test data, conclusions, and recommendations and shall forward copies of the report to the Chairman, Secretary, and members of the committee.

2. The committee sh:il1 study the report, review and evaluate the test results given in the report, shall formulate its own conclusions and reconmendations relative to the adequacy of the performance of the equipment, and 
shall report these conclusions and recommendations to the Respirator Kesearch and Development Section.

3. The Respirator Research and Development Section shall forward all conclusions and recommendations, including dissenting opinions, to oS.

4. OS shall consider the conclusions and recomnendations concerning the adequacy of the performance of the equipment and shall make a decision on whether or not to authorize use of the device. 